УдК [796.01:612+796.015.15]

ISSN (Ukrainian ed. Print) 1991-0177 ISSN (Ukrainian ed. Online) 1999-818X 2020, № 6(80), C.73-80 doi: $10.15391 /$ snsv.2020-6.011

\title{
Оперативні методи оцінки поточного функціонального стану спортсмена в системі тренувального процесу
}

\author{
Ярославна Пугач \\ Наталія Пащенко \\ Тамара Ляхова
}

Харківська державна академія фізичної культури, Харків, Україна

Мета: розробити метод індивідуальної оцінки поточного функціонального стану в організації тренувального процесу.

Матеріал і методи: використовувалися такі методи: аналіз і узагальнення науково-методичної літератури; узагальнення досвіду практичної роботи тренерського контингенту, що працює з контингентом груп спортивного вдосконалення в баскетболі; методи математичного моделювання і обробки відеоматеріалів спортивних змагань різного рівня з баскетболу; модернізована методика ортостатичної проби Н. Тесленко - проба «сидячи-стоячи».

Результати: індивідуальний метод оцінки функціонального стану в процесі проведення тренувального заняття дозволяє визначити міру його працездатності і готовності спортсмена до навантажень, що йому пред'являються. Практично розроблений метод дає можливість в реальному масштабі часу вести контроль за станом розвитку стомлення, оцінюючи тим самим рівень працездатності і давати об'єктивні оцінки індивідуальної витривалості. Слід зазначити, що модифікований метод ортостатичної проби Н. Тесленко при використанні сучасної комп'ютерної техніки дозволяє передавати на будь-якій відстані отриману інформацію і контролювати стан організму спортсмена, не обмежуючи його рухову діяльність.

Висновки: розроблений метод модифікованої ортостатичної проби Н. Тесленко дозволяє здійснювати ранню діагностику розвитку втоми, що попереджає таке явище як перевтома.

Ключові слова: втома, модифікована ортостатична проба Н. Тесленко, оцінка витривалості, оптимізація фізичного навантаження.

\section{Вступ}

У даний час все в більшій мірі зростає актуальність проблеми стомлюваності і відновлення після перенесеного навантаження. Проблемою стомлення займаються більш ніж дві сотні років [9].

Втома - це універсальне явище, властиве всьому живому: рослинам, тваринам і людині. Незважаючи на загальність цього явища і його велике наукове і практичне значення, відповідь на поставлене запитання дається в більшій мірі в описовій формі, не розкриваючи суті втоми і його фізіологічного механізму [3, 12, 19].

Найбільш широко використовується визначення, яке звучить як: стомлення - це тимчасове зниження працездатності, що викликається роботою, різною за характером, обсягом та інтенсивністю. Таке визначення не розкриває фізіологічного механізму втоми, так як зниження працездатності можна розглядати як наслідок втоми, а не як саму втому $[6,14,17]$.

3 різних напрямків вивчення втоми в повному, відповідно до наведеного визначення, широко здійснюється вивчення саме працездатності з тим, щоб за їі стадіям говорити про глибину втоми. Апаратурне дослідження стомлення починалося за допомогою міографії на ізольованих від організму нервово-м'язових препаратах, а також за допомогою ергографії.

Перші ергографічні конструкції А. Моссоі і І.М. Сеченова були призначені для контролю виконуваного фізичного навантаження окремих рухових актів з точною оцінкою обсягу виконаної роботи і її характеру за такими параметрами як її інтенсивність і тривалість. У подальшому цей метод був поширений на різного роду тетбани, бігові доріжки, вело ергографію та на інших приладах, що дозволяють враховувати обсяг і характер виконуваної фізичної роботи. Загальна особливість ергографічного методу вивчення процесу стомлення полягає в тому, що для них є тільки дослідження динамічної роботи. Статичні напруги не можуть бути виражені в них через використовувані одиниці виміру (кт / м). Тим більше це недоступно для оцінки енергетичних витрат, ступеня технічної діяльності, або трофічних енерговитрат в різних умовах перебування у будь-якому напруженому стані.

Проблема оцінки втоми розглядалася окремими вченими ще в XVII столітті. У міру розвитку фізіології і появи об'єктивних методів дослідження їх кількість значно збільшилася. Вже в 1925 році їх число перевищило 


\section{СЛОБОЖАНСЬКИЙ НАУКОВО-СПОРТИВНИЙ ВІСНИК}

понад 13 тисяч. Цій проблемі приділяли увагу Г. Гельмгольц, Е. Дюбуа-Реймон, А. Моссо, І.М. Сєченов, Ч. Шерінгтон, А.А. Ухтомський, К.М. Биков і цілий ряд інших фізіологів. Однак велика кількість робіт в даному питанні не дозволила до теперішнього часу не тільки розкрити теоретичні основи самого процесу, але навіть виробити єдине визначення. Термін «стомлення» $є$ одним 3 найбільш неточних в фізіології.

S.H. Bartley, E. Chute (1947), В.В. Розенблат (1975) у своїх роботах приводять до 100 різних визначень даного стану. Більше того, в ряді робіт можна почути думку, що даний термін ненауковий і його треба вилучити з ужитку. Природно, такий стан питання визначається його складністю. Втома як процес відображає стан організму і може трактуватися як ступінь відхилення від його функціонального оптимуму, тобто нормального стану.

Проблема норми вивчається протягом всієї історії розвитку біології і медицини і також має суттєві протиріччя в оцінці поняття норми, її трактування, аж до повного заперечення самого поняття. Природно, важко припустити, щоб взаємопов'язані проблеми знайшли вирішення з одного боку і залишалися нерозкритими з іншого. Однак, різноманітність підходів у вирішенні спільних питань дозволило доповнити уявлення про кожну з них.

Незважаючи на те, що ні у 1961 році на симпозіумі з проблеми втоми і відновлення працездатності при м'язової діяльності, ні у 1969 році на симпозіумі в Кіото не було вироблено єдиної думки у трактуванні фізіології стомлення і працездатності, проте, результати багаторічних досліджень дозволили в значній мірі розкрити цілу низку особливостей даного явища (Розенблат, 1973).

Настільки велика різниця думок і висновків про механізм стомлення пояснювалося тим, що різні автори використовували в своїх дослідженнях різні об'єкти від ізольованих органів і тканин до цілісного організму, застосовуючи при цьому найрізноманітніші режими роботи.

Саме ці роботи дозволили встановити певні уявлення про загальну біологічну основу стомлення, як деякого стану організму щодо його норми. Введення поняття «норми» зажадало визначення його змісту, так як рівень тимчасового зниження працездатності щодо її нормального прояву виступає кількісним виразом функціонального стану робочого органу і організму в цілому.

Сукупність умов, найбільш сприятливих для рівноважного стану цього процесу, можуть бути прийняті як норма. Можливість позитивних або негативних відхилень у цих умовах вимагає від організму певних резервних потенціалів. Чим цей потенціал більше, тим ширше зона коливання умов навколишнього середовища, доступна для даного організму. У практиці важливо знати, яким чином можна збільшити цей потенційний резерв для розширення зони знаходження організму або його систем і яким чином можна, не розширюючи зону коливань, забезпечити переміщення в іншу область, у сприятливі умови існування зі збереженням колишніх потенційних можливостей $[10,22,26]$.

Слід зазначити, що в цьому напрямку досить глибоко вивчені процеси, які визначають нормальний стан організму або окремого його органу, встановлені картини вікових змін, складені уявлення про те, як і в чому конкретно відбуваються ці зміни.

Зв'язок досліджень 3 науковими програмами, планами, темами. Дана робота виконувалася відпо- відно до теми Зведеного плану науково-дослідних робіт у сфері фізичної культури і спорту на 2011-2015 рр. за темою 2.6 «Теоретико-методичні засади удосконалення тренувального процесу та змагальної діяльності у структурі багаторічної підготовки спортсменів» (номер державної реєстрації 0111U001168).

Мета дослідження - розробити метод індивідуальної оцінки поточного функціонального стану в організації тренувального процесу.

\section{Завдання дослідження:}

1. Проаналізувати види існуючого контролю функціонального стану спортсменів у ситуативних видах спорту.

2. Визначити неспецифічні (універсальні) реакції організму на зовнішні чинники середовищ і механізми їх управління.

3. Встановити структуру неспецифічної (універсальної) реакції організму.

4. Визначити механізм дії неспецифічної реакції організму на стан організації тренувального процесу.

\section{Матеріал і методи дослідження}

У вирішенні поставлених завдань використовувалися такі методи: аналіз і узагальнення досвіду практичної роботи тренерського контингенту, що працюють з контингентом груп спортивного вдосконалення в баскетболі; методи математичного моделювання і обробки відеоматеріалів спортивних змагань різного рівня з баскетболу; модифікована методика ортостатичної проби Н. Тесленко - проба «сидячи-стоячи».

\section{Результати дослідження}

У даний час інтенсивно розробляються методи дистанційної оцінки функціонального стану спортсмена у процесі як тренувальної, так і змагальної діяльності. В основі їх лежить аналіз відеоматеріалів контрольованої рухової діяльності з подальшою обробкою кінематики переміщень центрів маси як окремих біокінематичних ланок, так і загального центру маси всього тіла $[11,21]$. Щодо цих методів, які вимагають досить складної і дорогої відеореєструючої техніки і відповідної програмної обробки оцінюваних рухових дій для подальшої оцінки заходів стомлення, у розглянутому нами методі використовується неспецифічна (універсальна) реакція, яка виступає частотною характеристикою скорочення серця або частоти серцевих скорочень.

Перевага цієї методики полягає в тому, що частотна характеристика відображає загальний стан організму незалежно від кінематичних або статичних фізичних навантажень, або психічних переживань, або в стані глибокого сну, тоді протікають трофічні процеси, які відображають динаміку протікаючого обміну речовин.

Даний метод було розроблено на підставі обстеження десятків тисяч студентів факультету фізичного виховання ХДПІ ім Г.С. Сковороди доцентом кафедри анатомії і фізіології Н. Тесленко. В основі розробленого методу закладено статистичну обробку змін частотної характеристики серцевих скорочень при виконанні ортостатичної проби «сидячи-стоячи». Спостерігаючи за реакцією частоти серцевих скорочень (ЧСС), відзначалися зміни частоти, у яких пульс стоячи був менше, ніж пульс сидячи; пульс стоячи дорівнював пульсу сидячи; 
пульс стоячи був вище пульсу сидячи. Статичній обробці підлягали дані вихідного стану (характерна частота пульсу в спокої, яка спостерігається в момент проведення обстеження, яка варіювала в обстежуваному масиві студентів в інтервалі від 39 ударів в хвилину до 120 ударів в хвилину).

В обстеженні брали участь студенти різного віку, статі, рівня спортивної кваліфікації, різних видів спорту. При виконанні стандартної ортостатичної проби паралельно виконувалася стандартна проба ергометричної рухової діяльності, яка полягала в триразовому п'ятисекундному заповненні на аркуші паперу точок, які наносяться з максимально можливою швидкістю. Ергометрична проба виконувалася як в положенні сидячи в режимі 3 рази по 5 секунд, так і в положенні стоячи після вимірювання пульсу за десятисекундний інтервал, в подальшому перерахунку число ударів в одну хвилину [4].

На підставі статистичної обробки ергометричних даних було складено шкалу оцінки стану обстежуваних респондентів, яка була переведена в індексові бали, зіставляються з частотними характеристиками реєстрованих за показаннями чСС в спокійному стані до виконання ортостатичної проби і відразу після її виконання, на підставі чого була складена шкала частотної характеристики ЧСС респондентів за результатами виконання проби.

Таким чином, розроблена таблиця індексової оцінки якісного стану серцево-судинної системи студентів при виконанні ортостатичної проби «сидячи-стоячи» (таблиця 1) включає в себе три виміри: індексову оцінку стану працездатності або міру стомлення (вісь аплікати Z); шкала зміни прирощення пульсу після виконання проби (вісь ординати Y); шкала частоти серцевих скорочень респондентів в спокійному стані перед виконанням ортостатичної проби (вісь абсцис X) (рис. 1.).

Проведений аналіз динаміки зміни частотних характеристик серцевих скорочень, реакцію альтерніруючого фактору дозволив встановити загальну закономірність, якою виступає експоненціальна залежність. Індивідуальна різниця її прояву пов'язана з коефіцієнтом кривизни цієї кривої, що і складає основу виконаної модифікації ортостатичної проби Н. Тесленко, перетворивши її на основі використання індивідуальної норми в індивідуальну оцінку поточного стану обстежуваного спортсмена.

Шкала оцінки поточного стану включала наступну градацію на 7 зон: 14-10,5- відмінний стан; до 8,5 - добрий стан; до 6,5 - вище середнього стан; 6,5 - середній; до 4,5 - нижче середнього; до 2,5 - поганий стан; до 1,5 - дуже поганий стан.

У кожного індивіда є діапазон зміни функціонального стану, який представляє шкалу стану. Крайні значення шкали стану від свого max до min визначають діапазон спостережуваних станів і $€$ оцінкою його фізичного стану. За своєю варіативністю прояв їх ймовірності виражається 3-сигмальною віддаленістю від найбільш часто повторюваної точки норми. У зв'язку з цим повний діапазон поділяється на шкалу стану з шести частин, які мають 7 граничних точок. Введення імовірнісної міри визначило ділення шкали станів на 7 зон з оцінкою їх якісного вираження в балах від 14 до 1,5.

У площині амплітудно-частотних взаємодій відповідної реакції організму на ортостатичну пробу протікає динаміка відносин в системі, що подається матрицею І-цзін. Вся варіативність цих відносин виражається в реальних частотно-амплітудних характеристиках реакції чСС на ортостатичну пробу, що представлено в таблиці індексової оцінки стану серцево-судинної системи.

Сутність табличного матеріалу представлення оцінки поточного стану фактично полягає в тому, що в ній міститься інформація тривимірного простору, яка складається з трьох незалежних шкал: шкали спостереження різниці реакції пульсу на ортостатичну пробу; шкали вихідного стану пульсу перед виконанням ортостатичної проби; школи індексової оцінки поточного стану організму.

Графічне представлення цієї інформації полягає в наступному: виходячи з того, що найбільш ефективна реакція організму на пробу характеризується при нульовій різниці на неї в частоті пульсу (швидкість виконання проби не розглядається). Вона повинна бути такою, щоб

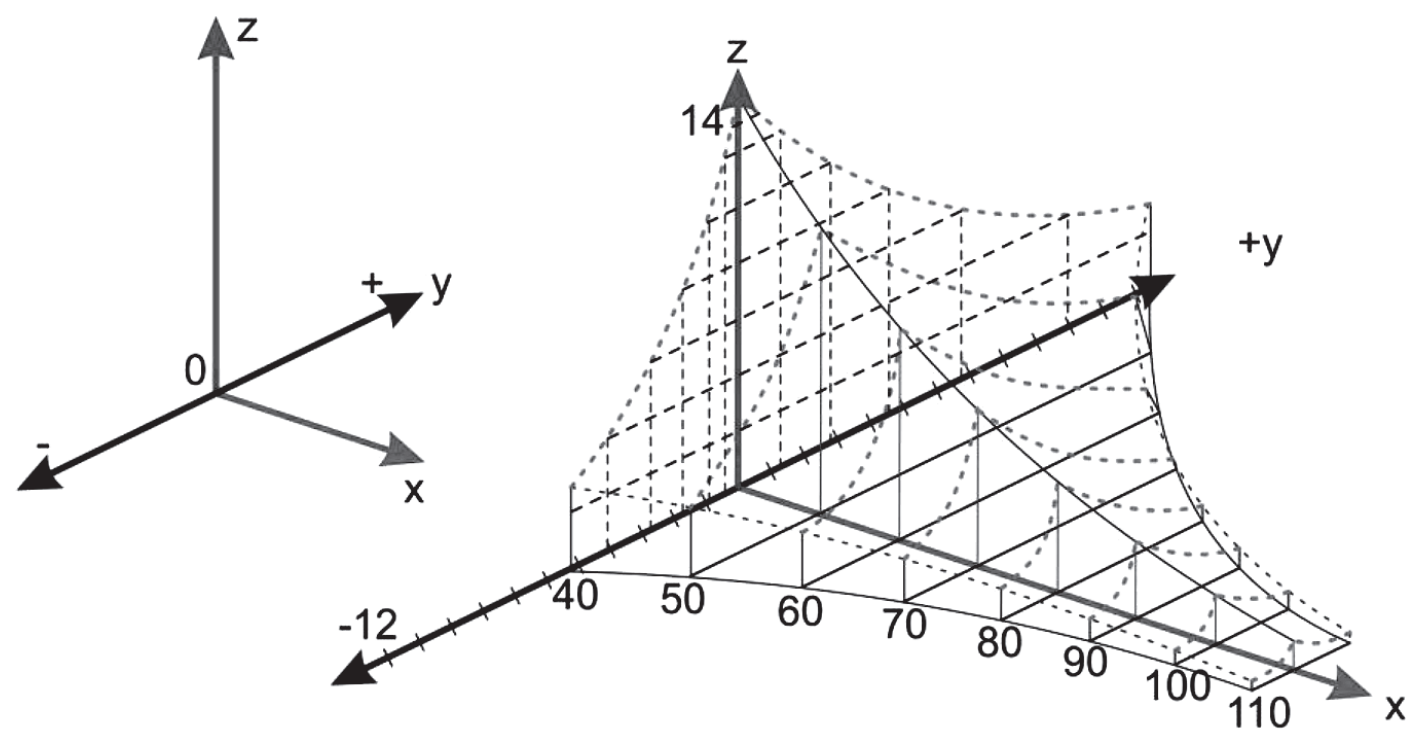

Рис. 1.

Три виміри таблиці індексової оцінки якісного стану серцево-судинної системи студентів при виконанні ортостатичної проби «сидячи-стоячи» 
Таблиця 1

Індексова оцінка якісного стану серцево-судинної системи студентів під час проведення ортостатичної проби “сидячи-стоячи»

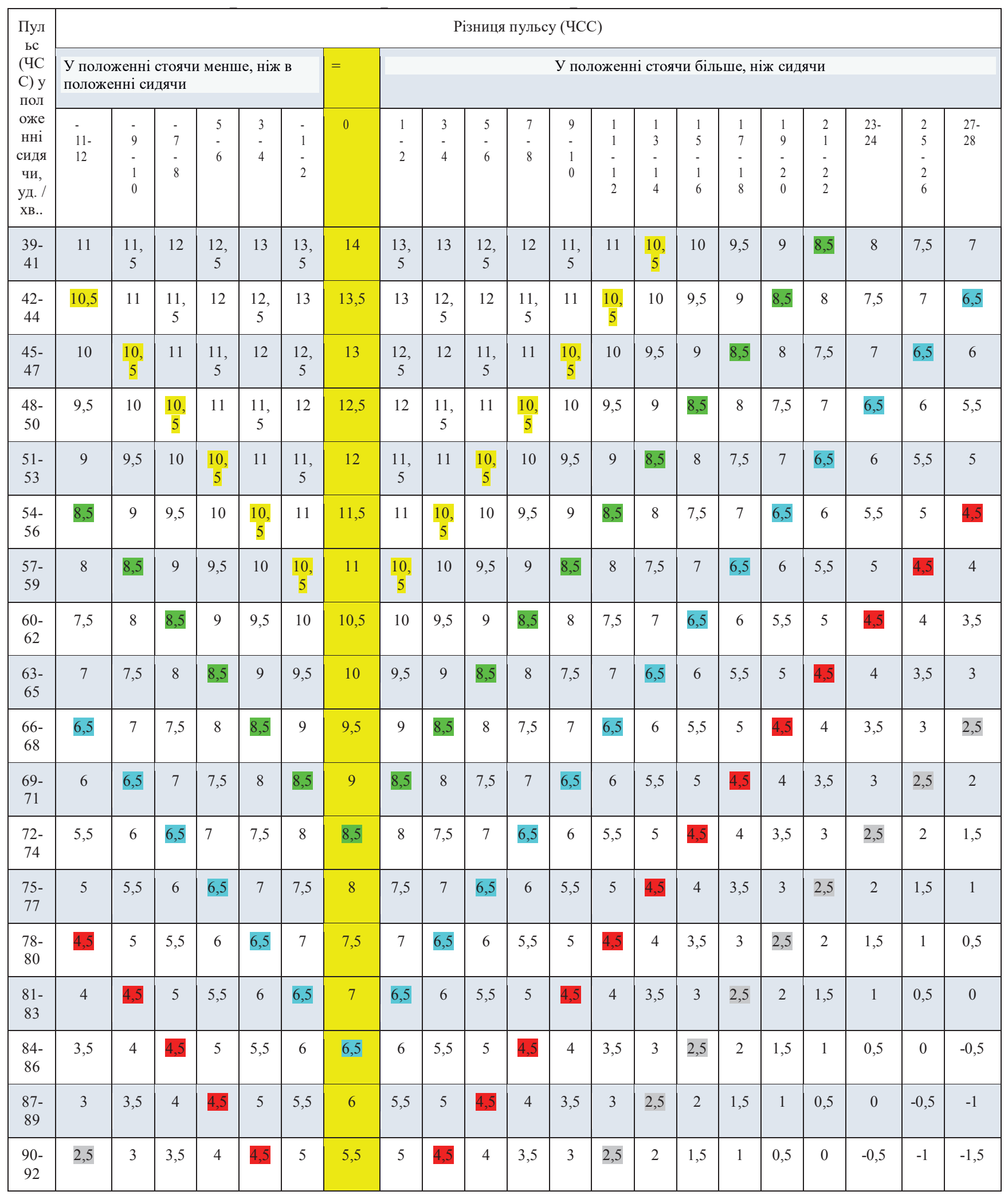




\begin{tabular}{|c|c|c|c|c|c|c|c|c|c|c|c|c|c|c|c|c|c|c|c|c|c|}
\hline $\begin{array}{c}93- \\
95\end{array}$ & 2 & 2,5 & 3 & 3,5 & 4 & 4,5 & 5 & 4,5 & 4 & 3,5 & 3 & 2,5 & 2 & 1,5 & 1 & 0,5 & 0 & $-0,5$ & -1 & $-1,5$ & -2 \\
\hline $\begin{array}{c}96- \\
98\end{array}$ & 1,5 & 2 & 2,5 & 3 & 3,5 & 4 & 4,5 & 4 & 3,5 & 3 & 2,5 & 2 & 1,5 & 1 & 0,5 & 0 & $-0,5$ & -1 & $-1,5$ & -2 & $-2,5$ \\
\hline $\begin{array}{c}99- \\
101\end{array}$ & 1 & 1,5 & 2 & 2,5 & 3 & 3,5 & 4 & 3,5 & 3 & 2,5 & 2 & 1,5 & 1 & 0,5 & 0 & $-0,5$ & -1 & $-1,5$ & -2 & $-2,5$ & -3 \\
\hline $\begin{array}{c}102- \\
105\end{array}$ & 0,5 & 1 & 1,5 & 2 & 2,5 & 3 & 3,5 & 3 & 2,5 & 2 & 1,5 & 1 & 0,5 & 0 & $-0,5$ & -1 & $-1,5$ & -2 & $-2,5$ & -3 & -3.5 \\
\hline $\begin{array}{c}106- \\
108\end{array}$ & 0 & 0,5 & 1 & 1,5 & 2 & 2,5 & 3 & 2,5 & 2 & 1,5 & 1 & 0,5 & 0 & $-0,5$ & -1 & $-1,5$ & -2 & $-2,5$ & -3 & $-3,5$ & -4 \\
\hline $\begin{array}{c}108- \\
110\end{array}$ & $-0,5$ & 0 & 0,5 & 1 & 1,5 & 2 & 2,5 & 2 & 1,5 & 1 & 0,5 & 0 & $-0,5$ & -1 & $-1,5$ & -2 & $-2,5$ & -3 & $-3,5$ & -4 & $-4,5$ \\
\hline $\begin{array}{c}112- \\
114\end{array}$ & -1 & $-0,5$ & 0 & 0,5 & 1 & 1,5 & 2 & 1,5 & 1 & 0,5 & 0 & $-0,5$ & -1 & $-1,5$ & -2 & $-2,5$ & -3 & $-3,5$ & -4 & $-4,5$ & -5 \\
\hline $\begin{array}{c}115- \\
117\end{array}$ & $-1,5$ & -1 & $-0,5$ & 0 & 0,5 & 1 & 1.5 & 1 & 0,5 & 0 & -0.5 & -1 & -1.5 & -2 & $-2,5$ & -3 & $-3,5$ & -4 & $-4,5$ & -5 & $-5,5$ \\
\hline
\end{tabular}

отримати нульову різницю. При цьому індексова оцінка буде 14. У разі іншого результату отриманий індекс буде відображений в точці відповідної різниці відповідно до табличних даних. Аналогічна операція виконується для кожного вихідного значення частоти пульсу перед виконанням проби.

Таким чином, в тривимірному просторі відображення табличних даних вісь (Z) апліката (вертикальна шкала) - це індексова оцінка стану. Ось (Y) ордината - це різниця пульсу на пробу. Ось (X) абсциса - це частота вихідного значення пульсу до виконання проби.

На відміну від ряду інших методів дистанційної оцінки поточного стану людини, які можуть давати досить точний аналіз тільки при відеореєстрації виконуваного рухового акту, модифікована проба Н. Тесленко заснована на неспецифічній (універсальній) реакції чСС на дію будь-якого альтеріруючого фактора будь-якої природи, що недоступно будь-якій методиці дистанційного контролю і оцінки поточного функціонального стану. Модифікація проби Н. Тесленко стала можливою при введенні стандарту порівняння, яким виступає індивідуальна норма стану і його доступна норма варіації. У кожному конкретному випадку, який визначається специфікою даної професійної діяльності, формується якісна оцінка кінцевого результату цієї діяльності, що характеризує її ранг виконання. Відповідно до професійної діяльності за повною аналогією з модифікацією проби Н. Тесленко здійснюється оцінка поточного стану.

3 інтенсифікацією виробничої діяльності контроль поточного стану людини в системі «людина-машинасередовище» або «людино-машинних» систем стає все більш актуальним завданням, і її вирішення ще не знайдено. Причина такого стану питання полягає в тому, що в кожному конкретному випадку для оцінки поточного стану використовується, як критерій порівняння, так і поняття «норми», але не враховується порівняння, з якою нормою йде це зіставлення: із загальною, універсальною, що відображає неспецифічну реакцію організму, на що впливає альтеріруючий фактор, що виступає аналогом модифікованої ортостатичної проби Н. Тесленко, або з нормою кінцевого результату спеціалізованої професійної діяльності, або одночасно використовуються неспецифічна універсальна норма і спеціалізована, що також має місце при вирішенні низки практичних завдань.

Використання практики оцінки заходів стомлення за динамікою ЧСС як неспецифічної універсальної реакції не $€$ єдиною. Такими можуть виступати частота дихання, рН слини і крові, міра набухання тканини і цілий ряд інших реакцій, що відображають постійність внутрішнього середовища (її гомеостазу). Використання ЧСС в контролі прояви спостережуваної динаміки змін найбільш доступні та існує досить велика кількість засобів, що забезпечують їх реєстрацію. Однак, в обробці отриманої інформації і її інтерпретації відсутнє розуміння і виділення характеристики індивідуальної норми і динаміки її поведінки в адаптаційних процесах цілісного організму. Зокрема, контроль міри втоми і залишкового потенціалу для подальшого виконання певної інтенсивності заданої роботи.

Фактично, виконана індексова оцінка якісної характеристики серцево-судинної системи в ортостатичній пробі «сидячи-стоячи» несе в собі інформацію про міру стомлення в змісті середньостатистичного розуміння її норми, так як це випливає з принципу збору самої інформації. Основна заслуга розробки індексової оцінки поточного стану обстежуваного полягає в тому, щоб, не виконуючи будь-яке навантаження, визначити міру втоми лише за даними зміни ЧСС. В умовах виконання тесту зазначалася необхідність швидкої зміни пози «сидячи-стоячи». Тест розроблявся як альтернатива широко використовуваного тесту С.П. Летунова, який складався з трьох послідовних навантажень різної інтенсивності і тривалості: 20 присідань, 15-секундний біг на місці з максимальною швидкістю і 3-хвилинний біг на місці в темпі 180 кроків за хвилину. Проба Летунова займала 5 хвилин, могла проводитися до тренувального заняття і після, заснована на середньостатистичних даних норми умовного здорового індивіда [5].

Проба Н. Тесленко займала 10 секунд, могла проводитися протягом тренувального заняття з використанням таблиці індексової оцінки поточного стану. Поняття 


\section{СЛОБОЖАНСЬКИЙ НАУКОВО-СПОРТИВНИЙ ВІСНИК}

індивідуальної норми в той період часу повністю було відсутнє, але структура побудови індексової оцінки містила в собі цю інформацію.

При модифікації тесту Н. Тесленко і розробленої теорії індивідуальної норми в результаті тривимірного представлення її змісту були розкриті умови встановлення індивідуальної норми, а отже, і поточного стану працездатності або втоми за показаннями удару пульсу.

Представляючи наступний удар, як реакцію зміни стану щодо попереднього стану, необхідно встановити спостереження збільшення, що призвело до понять «норми стану» і «стан індивідуальної норми». Представлення динаміки поведінки збільшень щодо деякого стану відображають порушення гомеостазу внутрішнього середовища на навантаження, які переносяться. Індивідуальною нормою вважається 0-різниця приросту при зміні пози «сидячи-стоячи». При аналізі таблиці даних випливає, що змінюючи швидкість підйому вставання, завжди можна домогтися цього ефекту. Цей режим навантаження буде виступати нормою стану. 3 огляду на сучасну мініатюризацію сенсорних датчиків і комп'ютерні можливості отриманого сигналу можна вважати, що поставлена мета повністю досягнута.

Якщо замість амплітудно-частотної характеристики коливання стінки судини взяти будь-який інший показник коливання кінцевого еквіфінального результату виконуваної професійної діяльності, то закономірність його поведінки не змінюється. Отже, як неспецифічна універсальна реакція, так і диференційована спеціалізована реакція носять єдину природу механізму їх побудови і складають структуру комплексу безперервного діагностичного контролю поточного стану спостережуваного індивіда.

\section{Висновки / Дискусія}

Попередній досвід спортивної медицини показує, що амплітудно-частотна реакція гладкої мускулатури артеріальних судин має дві протилежні спрямованості своєї реакції на дію гідростатичного удару ортостатичної проби. В одному випадку це проявляється в збільшенні їх тонусу напруги і прояві гіпертонічної реакції, в іншому - спостерігається зниження тонусу і прояв гіпотонічної реакції. Зміна тонусу напруги судин тісно пов'язана зі зміною частотної характеристики скорочення серцевої мускулатури (за принципом гіперболічної залежності), що лежить в основі фізіологічного механізму роботи поперечно-смугастих м'язів [18].

Ця реакція регуляції тонусу судин визначається необхідністю регуляції величини значення сталості збереження пульсового тиску при постійній динаміці систолічного і діастолічного тиску. В цілому, ця динаміка характеризується дев'ятьма різними напрямками його зміни і сімома рангами зміни сили відхилень від норми напруги. Залежно від величини порушення норми спрямованість накопичення втоми розвиває незворотні патологічні порушення [16, 25].

Здійснення систематичного моніторингу за відхиленнями від норми процесу оптимальної регуляції дає можливість виявлення і прогнозу виникаючих професійних захворювань, на чому заснована діагностика за 7-бальною градаціїєю від синдрому до симптомів, а потім до продрому $[1,8,14]$.

Систематизація отриманих результатів дозволяє зробити наступні висновки: в основі протікаючих фізіологічних процесів, що визначають морфо- функціональні зміни в організмі, лежать аналітичні закономірності. Це дозволяє здійснювати контроль розвитку порушень і своєчасно попереджати їх прояви.

Аналітичні закономірності, які виявлені у контролі динаміки амплітудно-частотних змін ЧСС, є: періодичні прояви, що відображаються в тригонометричних функціях, гіперболічних залежностях, ланцюговій лінії, циклоїдальних залежностях, арифметичній і геометричній прогресіях, які в своїх взаємозумовлених відносинах призводять до констант, чисельні вираження яких представляють собою нескінченні дроби. Їх округлення в практиці реально протікаючих процесів визначає толерантність простору відносин, що обмежує складність побудови системи відносин. Індивідуальні прояви загальних закономірностей пов'язані з коефіцієнтом, що визначає кривизну зазначених аналітичних виразів. Особливість поведінки зазначених закономірностей полягає в дискретному характеру їх прояву.

Перспективи подальших досліджень планується побудова єдиної системи контролю розвитку втоми для всіх ситуаційних видів спортивної діяльності, заснованої на використанні універсальної (неспецифічної) реакції організму, яка виникає у відповідь на зміну статичної напруги, контролюючи тільки її ранг.

Конфлікт інтересів. Автори заявляють, що відсутній конфлікт інтересів, який може сприйматись таким, що може завдати шкоди неупередженості статті.

Джерела фінансування. Ця стаття не отримала фінансової підтримки від державної, громадської або комерційної організації.

\section{Список посилань}

1. Артемьева Г. П., Пугач Я. И., Друзь В. А. (2014), Проблемы адаптации в структуре научных исследований системь олимпийского образования: монография, Харьков: ХГАФК, $114 \mathrm{c.}$

2. Ашанин В. С., Пугач Я. И. (2014), Построение семантических пространств для описания психосоматической деятельности человека в экстремальных условиях: уч. пособие, Харьков: ХГАФК, 88 с.

3. Бабский Е. Б., Зубков А. А., Косицкий Г. И., Ходоров Б. И. (1966), Физиология человека, Москва: Медицина, С. 370-379.

4. Баканова А. Ф. (2013), Организация физического воспитания студенческой молодежи на современном этапе реформирования высших учебных заведений: диссертация канд. наук : 24.00.02, Харьков, 248 с.

5. Васильева В. В., Граевская Н. Д., Кукалевский Г. М. (1961), Спортивная медицина, Москва: Медиздат, С. 207, $233-235$.

Пугач, Я., Пащенко, Н., Ляхова, Т. (2020), «Оперативні методи оцінки поточного функціонального стану спортсмена в систем тренувального процесу» 
6. Волков В. М. (1977), Восстановительные процессы, Москва: Физкультура и спорт, 143 с.

7. Волкова Я. (2020), «Сучасні методи оцінки стомлення», Слобожанський науково-спортивний вісник, № 4 (78), С. 30-36.

8. Гика М. (1936), Эстетика пропорций в природе и искусстве, Москва: Всесоюзная академия архитектуры, С. 119-120. спорт, 56 с

9. Гиппенрейтер Ю. Б. (1966), Восстановительные процессы при спортивной деятельности, Москва: Физкультура и

10. Друзь В. А. (1985), Анализ общих принципов функциональных отношений систем организма в динамике: диссертация д-ра биол. наук : 05.13.09, АНУССР. Киев, 504 с.

11. Друзь В. А., Омельченко М. В., Омельченко Д. А. (2015), “Основи техніки спринтерського бігу», Слобожанський науково-спортивний вісник, № 3 (47), С. 41-46.

12. Зимкин Н. В. (1964), Физиология человека, Москва: Физкультура и спорт, С. 381-398.

13. И-цзин (2016), Книга перемен, Москва: Азбука-Аттикус, 576 с.

14. Марков Г. В. (2006), Система восстановления и повышения работоспособности в спорте высших достижений, Москва: Советский спорт, 52 с.

15. Пугач Я. И. (2013), «Основные положения построения семантических пространств для упорядоченного представления результатов исследований», Бъдещего вопросы от света на надката: материалы IX международной научно-практической конференции, София, С. 5-13.

16. Пугач Я. И. (2014), Влияние эмоционального состояния на успешность соревновательной деятельности: диссертация канд. наук по физ. восп. и спорту: 24.00.01, ХГАФК, Харьков, 198 с.

17. Розенблан В. В. (1976), Проблемы утомления, Москва: Медицина, 220 с.

18. Самсонкин В. Н., Друзь В. А., Федорович В. С. (2010), Моделирование в самоорганизующихся системах, Донецк, 104 с.

19. Фарфель В. С. (1960), Физиология спорта, Москва: Физкультура и спорт, С. 301-311.

20. Чжоу Цзунхуа, Дао И-цзина. (1999), Путь к прорицанию, Киев: София, 368 с.

21. Шестерова Л., Друзь В., Ефременко А. (2017), «Анализ кинематических характеристик движения общего центра массы тела спортсмена при выполнении низкого старта», Слобожанський науково-спортивний вісник, № 2 (58), С. 113-118.

22. Hirata K. (1968), The evaluating method of physique and physical fitness and its practical application, $240 \mathrm{p}$.

23. Hoffman J., Mohri M., \& Zhang N. (2018), Algorithms and Theory for MultipleSource Adaptation, CoRR 805 p.

24. Hristovski R., Balague Serre N., \& Schollhom W. (2014), «Basic notions in the science of complex systems and nonlinear dynamics", Complex Systems in Sport. London, UK: Routledge, pp. 3-17.

25. Sheldon W. H., Lewis N. D. C., Tenney A. (1969), Psychotic patterns and physical constitution, N.Y., 325 p.

26. Zadeh L. A. (2015), Fuzzy logic - a personal perspective, Fussy Sets and Systems, 281 p.

Стаття надійшла до редакції: 08.12.2020 p.

Опубліковано: 21.12.2020 p.

Аннотация. Ярославна Пугач, Наталия Пащенко, Тамара Ляхова. Оперативные методы оценки текущего функционального состояния спортсмена в системе тренировочного процесса. Цель: разработать метод индивидуальной оценки текущего функционального состояния в организации тренировочного процесса. Материалы и методы: использовались следующие методы: анализ и обобщение научно-методической литературы; обобщение опыта практической работы тренерского контингента, работающего с контингентом групп спортивного совершенствования в баскетболе; методы математического моделирования и обработки видеоматериалов спортивных соревнований различного уровня по баскетболу; модернизированная методика ортостатической пробы Н. Тесленко - проба «сидя-стоя». Результаты: индивидуальный метод оценки функционального состояния в процессе проведения тренировочного занятия позволяет определить меру его работоспособности и готовности спортсмена к предьявляемым ему нагрузкам. Практически разработанный метод дает возможность в реальном масштабе времени ввести контроль состояния развиваемого утомления, оценивая тем самым уровень работоспособности и давать объективные оценки индивидуальный выносливости. Следует отметить, что метод модифицированной ортостатической пробы H. Тесленко при использовании современной компьютерной техники позволяет передавать на любом расстоянии полученную информацию и контролировать состояние организма спортсмена, не ограничивая его двигательную деятельность. Выводы: разработанный метод модифицированной ортостатической пробы Н. Тесленко позволяет осуществлять раннюю диагностику развития усталости, что предотвращает износ организма и упреждает такое явление как переутомление.

Ключевые слова: утомление, модифицированная ортостатическая проба Н. Тесленко, оценка выносливости, оптимизация физической нагрузки.

Abstract. Yaroslavna Puhach, Natalya Pashchenko, Tamara Lyakhova. Operational methods of estimating the current functional sportsman's state in the system of training process. Purpose: to develop the methodology for an individual assessment of the current functional state when organizing the training process. Materials and methods: the following methods were used: analysis and generalization of scientific and methodological literature; generalization of the experience of the practical work of the coaching contingent working with the contingent of sports improvement groups in basketball; methods of mathematical modeling and processing of video materials of sports competitions of various levels in basketball; the modernized method of orthostatic test by N. Teslenko - test "sitting-standing". Results: an individual method for assessing the functional state in the process of conducting the training lesson allows to determine the measure of working capacity and the athlete's readiness to the loads presented. The practically developed method makes it possible to introduce control over the state of developed fatigue in real time, thereby assessing the level of performance and giving objective assessments of individual endurance. In practice, the developed method makes it possible to introduce control over the state of developing fatigue in real time, thereby assessing the level of performance and giving objective assessments of individual endurance. It should be noted that the modified method of N. Teslenko orthostatic test with the use of modern computer technology makes it possible to transmit the information received at any distance and control the state of the athlete's body without restricting his motor activity. Conclusions: the developed technique of the modified orthostatic test by N. Teslenko allows early diagnosis of the development of fatigue, which prevents the deterioration of the body and prevents the phenomena of fatigue.

Keywords: fatigue, modified orthostatic test by N. Teslenko, assessment of endurance, optimization of physical activity. 


\section{СЛОБОЖАНСЬКИЙ НАУКОВО-СПОРТИВНИЙ ВІСНИК}

\section{References}

1. Artemeva, G. P., Pugach, Ya. I., Druz, V. A. (2014), Problemyi adaptatsii vstrukture nauchnyih issledovaniy sistemyi olimpiyskogo obrazovaniya [Adaptation problems in the structure of scientific research of the Olympic education system], monografiya, Harkov, HGAFK, 114 p. (in Russ).

2. Ashanin, V. S., Pugach, Ya. I. (2014), Postroenie semanticheskih prostranstv dlya opisaniya psihosomaticheskoy deyatelnosti cheloveka v ekstremalnyih usloviyah [Construction of semantic spaces to describe the psychosomatic activity of a person in extreme conditions], uch. posobie, Harkov: HGAFK, 88 p. (in Russ).

3. Babskiy, E. B., Zubkov, A. A., Kositskiy, G. I., Hodorov, B. I. (1966), Fiziologiya cheloveka [Human physiology], Moskva: Meditsina, pp. 370-379. (in Russ).

4. Bakanova, A. F. (2013), Organizatsiya fizicheskogo vospitaniya studencheskoy molodezhi na sovremennom etape reformirovaniya vyisshih uchebnyih zavedeniy [Organization of physical education of student youth at the present stage of reforming higher educational institutions], dissertatsiya kand. nauk : 24.00.02, Harkov, 248 p. (in Russ).

5. Vasileva, V. V., Graevskaya, N. D., Kukalevskiy, G. M. (1961), Sportivnaya meditsina [Sports medicine], Moskva: Medizdat, pp. 207, 233235. (in Russ).

6. Volkov, V. M. (1977), Vosstanovitelnyie protsessyi [Recovery processes], Moskva: Fizkultura i sport, 143 p. (in Russ).

7. Volkova, Ya. (2020), «Modern methods of fatigue assessment», Slobozhanskyi naukovo-sportyvnyi visnyk, No. 4 (78), pp. 30-36. (in Ukr.).

8. Gika, M. (1936), Estetika proportsiy v prirode i iskusstve [Aesthetics of proportions in nature and art], Moskva: Vsesoyuznaya akademiya arhitekturyi, pp. 119-120, 262-263. (in Russ).

9. Gippenreyter, Yu. B. (1966), Vosstanovitelnyie protsessyi pri sportivnoy deyatelnosti [Recovery processes in sports activities], Moskva: Fizkultura i sport, 56 p. (in Russ).

10. Druz, V. A. (1985), Analiz obschih printsipov funktsionalnyih otnosheniy sistem organizma v dinamike [Analysis of general principles of functional relationships of body systems in dynamics] : dissertatsiya d-ra biol. nauk : 05.13.09, ANUSSR. Kiev, 504 p. (in Russ).

11. Druz, V. A., Omelchenko, M. V., Omelchenko, D. A. (2015), «Sprint technique basics», Slobozhanskyi naukovo-sportyvnyi visnyk, No. 3 (37), pp. 41-46. (in Russ).

12. Zimkin, N. V. (1964), Fiziologiya cheloveka [Human physiology], Moskva: Fizkultura i sport, pp. 381-398. (in Russ).

13. I-tszin (2016), Kniga peremen [Book of Changes], Moskva: Azbuka-Attikus, 576 p. (in Russ).

14. Markov, G. V. (2006), Sistema vosstanovleniya i povyisheniya rabotosposobnosti v sporte vyisshih dostizheniy [System of recovery and improvement of performance in elite sports], Moskva: Sovetskiy sport, 52 p. (in Russ).

15. Pugach, Ya. I. (2014), Vliyanie emotsionalnogo sostoyaniya na uspeshnost sorevnovatelnoy deyatelnosti [The influence of the emotional state on the success of competitive activity]: dissertatsiya kand. nauk po fiz. vosp. i sportu : 24.00.01, Harkov: HGAFK, 198 p. (in Russ).

16. Pugach, Ya.I. (2013), «Basic principles of constructing semantic spaces for the orderly presentation of research results», B'deschego voprosyi ot sveta na nadkata: materialyi IX mezhdunarodnoy nauchno-prakticheskoy konferentsii, Sofiya, pp. 5-13 (in Russ).

17. Rozenblan, V. V. (1976), Problemyi utomleniya [Fatigue problems], Moskva: Meditsina, 220 p. (in Russ).

18. Samsonkin, V. N., Druz, V. A., Fedorovich, V. S. (2010), Modelirovanie v samoorganizuyuschihsya sistemah [Modeling in self-organizing systems], Donetsk, 104 p. (in Russ).

19. Farfel, V. S. (1960), Fiziologiya sporta [Physiology of sports], Moskva: Fizkultura i sport, pp. 301-311. (in Russ).

20. Chzhou Tszunhua, Dao I-tszina (1999), Put k proritsaniyu [The path to divination], Kiev: Sofiya, 368 p. (in Russ).

21. Shesterova, L., Druz, V., Efremenko, A. (2017), «Analysis of the kinematic characteristics of the movement of the general center of body mass of an athlete when performing a low start», Slobozhanskyi naukovo-sportyvnyi visnyk, No. 2 (58), pp. 113-118. (in Russ).

22. Hirata K. (1968), The evaluating method of physique and physical fitness and its practical application, 240 p. (in Eng)

23. Hoffman J., Mohri M., \& Zhang N. (2018), Algorithms and Theory for MultipleSource Adaptation, CoRR 805 p. (in Eng)

24. Hristovski R., Balague Serre N., \& Schollhom W. (2014), «Basic notions in the science of complex systems and nonlinear dynamics», Complex Systems in Sport. London, UK: Routledge, pp. 3-17. (in Eng)

25. Sheldon W. H., Lewis N. D. C., Tenney A. (1969), Psychotic patterns and physical constitution, N.Y., 325 p. (in Eng)

26. Zadeh L. A. (2015), Fuzzy logic - a personal perspective, Fussy Sets and Systems, 281 p. (in Eng)

Received: 08.12.2020.

Published: 21.12 .2020

\section{Відомості про авторів / Information about the Authors}

Пугач Ярославна Ігорівна: к. фіз.вих., доцент; Харківська державна академія фізичної культури: вул. Клочківська, 99, Харків, 61058, Україна.

Пугач Ярославна Игоревна: к.физ.восп., доцент; Харьковская государственная академия физической культуры: ул. Клочковская, 99, Харьков, 61058, Украина.

Yaroslavna Puhach: PhD (Physical Education and Sport); Kharkiv State Academy of Physical Culture: Klochkivska str. 99, Kharkiv, 61058, Ukraine.

ORCID.ORG/0000-0001-5460-772X

E-mail: sanadruz@gmail.com

Пащенко Наталія Олександрівна: Харківська державна академія фізичної культури: вул. Клочківська, 99, Харків, 61058, Україна.

Пащенко Наталия Александровна: Харьковская государственная академия физической культуры: ул. Клочковская, 99, Харьков, 61058, Украина.

Natalya Pashchenko: Kharkov State Academy of Physical Culture: Klochkivska str. 99, Kharkiv, 61058, Ukraine.

ORCID ORG/0000 0003-3219-9248

E-mail: paschenko1974@ukr.net

Ляхова Тамара Петрівна: Харківська державна академія фізичної культури: вул. Клочківська, 99, Харків, 61058, Україна.

Ляхова Тамара Петровна: Харьковская государственная академия физической культуры: ул. Клочковская, 99, Харьков, 61058, Украина.

Tamara Lyakhova: Kharkov State Academy of Physical Culture: Klochkivska str. 99, Kharkiv, 61058, Ukraine.

ORCID ORG/0000-0003-4853-0513

E-mail: tamaraliahova29@gmail.com 